\title{
Analysis of Selective Androgen Receptor Modulators by Gas Chromatography-Microchip Atmospheric Pressure Photoionization-Mass Spectrometry
}

\author{
Laura Luosujärvi, ${ }^{\text {a }}$ Markus Haapala, ${ }^{\mathrm{b}}$ Mario Thevis, ${ }^{\mathrm{c}}$ Ville Saarela, ${ }^{\mathrm{d}}$ \\ Sami Franssila, ${ }^{\mathrm{d}}$ Raimo A. Ketola, ${ }^{\mathrm{e}}$ Risto Kostiainen, ${ }^{\mathrm{b}}$ and \\ Tapio Kotiaho ${ }^{\mathrm{a}, \mathrm{b}}$ \\ ${ }^{a}$ Laboratory of Analytical Chemistry, Department of Chemistry, University of Helsinki, Helsinki, Finland \\ ${ }^{\mathrm{b}}$ Division of Pharmaceutical Chemistry, Faculty of Pharmacy, University of Helsinki, Helsinki, Finland \\ ${ }^{\mathrm{c}}$ Center for Preventive Doping Research-Institute of Biochemistry, German Sport University Cologne, \\ Cologne, Germany \\ ${ }^{\mathrm{d}}$ Department of Micro and Nanosciences, Helsinki University of Technology, Helsinki, Finland \\ e Center for Drug Research, Faculty of Pharmacy, University of Helsinki, Helsinki, Finland
}

A gas chromatography-microchip atmospheric pressure photoionization-mass spectrometric (GC$\mu \mathrm{APPI}-\mathrm{MS}$ ) method was developed and used for the analysis of three 2-quinolinone-derived selective androgen receptor modulators (SARMs). SARMs were analyzed from spiked urine samples, which were hydrolyzed and derivatized with $N$-methyl- $N$-(trimethylsilyl)trifluoroacetamide before analysis. Trimethylsilyl derivatives of SARMs formed both radical cations $\left(\mathrm{M}^{+} \cdot{ }^{\bullet}\right)$ and protonated molecules $\left([\mathrm{M}+\mathrm{H}]^{+}\right)$in photoionization. Better signal-to-noise ratios $(\mathrm{S} / \mathrm{N})$ were obtained in MS/MS analysis using the $\mathrm{M}^{+} \cdot$ ions as precursor ions than using the $[\mathrm{M}+\mathrm{H}]^{+}$ions, and therefore the $\mathrm{M}^{+}$ions were selected for the precursor ions in selected reaction monitoring (SRM) analysis. Limits of detection (LODs) with the method ranged from 0.01 to $1 \mathrm{ng} / \mathrm{mL}$, which correspond to instrumental LODs of $0.2-20 \mathrm{pg}$. Limits of quantitation ranged from 0.03 to $3 \mathrm{ng} / \mathrm{mL}$. The mass spectrometric response to the analytes was linear $(R \geq 0.995)$ from the LOQ concentration level up to $100 \mathrm{ng} / \mathrm{mL}$ concentration, and intra-day repeatabilities were $5 \%-9 \%$. In addition to the GC- $\mu$ APPI-MS study, the proof-of-principle of gas chromatography-microchip atmospheric pressure chemical ionization-Orbitrap MS (GC- $\mu$ APCI-Orbitrap MS) was demonstrated. (J Am Soc Mass Spectrom 2010, 21, 310-316) @ 2010 American Society for Mass Spectrometry

$\mathrm{M}$ iniaturization of analytical devices has gained a lot of attention in recent years, and a multitude of papers concerning the topic has been published [1-3]. In mass spectrometry, the majority of the effort has been put to miniaturization of ion sources, especially electrospray ionization (ESI) [4]. However, other miniaturized ion sources, e.g., the heated nebulizer microchip for atmospheric pressure chemical ionization $(\mu \mathrm{APCI})[5]$ and atmospheric pressure photoionization ( $\mu$ APPI) [6], and the nebulizer microchip for sonic spray ionization (SSI) [7], have been reported as well. The heated nebulizer microchips can be used to connect a capillary liquid chromatograph (cap LC) $[8,9]$ or a gas chromatograph (GC) [9-11], with any mass spectrometer with an atmospheric pressure ionization (API) source, or as a heated sprayer in desorption atmospheric pressure photoionization [12]. In addition, the heated nebulizer microchips have been shown to be

Address reprint requests to Ms. L. Luosujärvi, Department of Chemistry, University of Helsinki, P.O. Box 55, FI-00014 University of Helsinki, Finland. E-mail: laura.luosujarvi@helsinki.fi suitable for the analysis of steroids [8,9], polyaromatic hydrocarbons [9], and drugs of abuses [13, 14], as well as for quantitation of polychlorinated biphenyls from soil samples [11].

Selective androgen receptor modulators (SARMs) are an emerging group of pharmaceutical compounds [15-17], which can be used in treatment of various diseases, such as osteoporosis, cachexia related to cancer, and HIV wasting [18-20]. Contrary to anabolic steroids, these compounds are tissue selective-the desired anabolic effects in muscles and bones are separate from the undesired androgenic effects-which make them attractive for treatment of diseases as well as testing for illegal purposes such as doping in sports. Analysis of SARMs in doping testing has an increasing importance since the number of drug candidates with anabolic effects is continuously growing [21]. SARMs based on the structures of for example aryl propionamide [22, 23], quinoline [24], 2-quinolinone [25], and hydantoin [26] have been reported, and analytical methods for 2-quinolinone-derived SARMs by liquid chromatography-electrospray ionization-mass spectrome- 
try (LC-ESI-MS) [27] and gas chromatography-electron impact ionization-mass spectrometry (GC-EI-MS) [28] have been published. In this study, three nonsteroidal androgen receptor modulators derived from 2-quinolinone, including the drug candidate LGD-2226 [25, 29, 30], were analyzed in urine after enzymatic hydrolysis and derivatization by the combination of gas chromatography and microchip atmospheric pressure photoionization-tandem mass spectrometry (GC- $\mu$ APPI-MS/MS). The high resolving power of GC and the high sensitivity provided by $\mu$ APPI together with selected reaction monitoring (SRM) analysis with a triple-quadrupole MS shows potential in doping analysis as shown below. In addition, the possibility to couple the API microchip with a high-resolving power Orbitrap MS, enabling highresolution MS analysis together with GC, is demonstrated (GC- $\mu$ APCI-Orbitrap MS). While the advantages of the heated nebulizer microchip for analytical work, i.e., high sensitivity and an insignificant dead volume, have been demonstrated in previous studies [9, 11], this study further shows the feasibility of the heated nebulizer microchip in bioanalytical applications. In comparison with the matrices in the previous GC- $\mu$ APPI-MS and GC- $\mu$ APCI-MS applications, the biological sample matrix of the present study is more challenging.

\section{Experimental}

\section{Chemicals}

Water was purified with a Milli-Q water purifying system (Millipore, Molsheim, France). Methanol and acetic acid were purchased from Mallinckrodt Baker B.V. (Deventer, The Netherlands), N-methyl$\mathrm{N}$-(trimethylsilyl)trifluoroacetamide (MSTFA), type HP-2 $\beta$-glucuronidase, ethyl acetate, sodium acetate, and toluene were from Sigma-Aldrich (Buchs, Switzerland and Steinheim, Germany). Oasis HLB solid-phase extraction (SPE) cartridges, $3 \mathrm{cc}$, were purchased from Waters (Milford, MA, USA). 2-Quinolinone derived SARMs (6-bistrifluoroethylamino-, 6-bisethylamino-, 6- $n$-propyl-4-trifluoromethylquinolin-2(1H)-ones) (Structures 1,2, and 3, respectively) were synthesized at the Center for Preventive Doping Research (Institute of Biochemistry, German Sports University, Cologne, Germany) [30].<smiles>O=c1cc(C(F)(F)F)c2cc(N(CC(F)(F)F)CC(F)(F)F)ccc2[nH]1</smiles>

Compound A

6-bistrifluoroethylamino4-trifluoromethylquinolin-2(1H)-one<smiles>CCN(CC)c1ccc2[nH]c(=O)cc(C(F)(F)F)c2c1</smiles>

Compound B

6-bisethylamino4-trifluoromethylquinolin-2(1H)-one

Structure 2

\section{Sample Preparation}

One $\mathrm{mL}$ of urine was spiked with the three SARM compounds dissolved in ethyl acetate $(10 \mu \mathrm{L})$. $\mathrm{pH}$ was adjusted to 5 by adding $0.75 \mathrm{~mL}$ of aqueous buffer $(0.2$ $\mathrm{M}$ sodium acetate, $\mathrm{pH}$ adjusted with acetic acid to 5), and $20 \mu \mathrm{L}$ of $\beta$-glucuronidase was added to the sample. The solution was incubated at $50{ }^{\circ} \mathrm{C}$ for $60 \mathrm{~min}$, and the SARMs were extracted with SPE. Before the extraction, the SPE cartridge was conditioned with $1 \mathrm{~mL}$ of methanol and $1 \mathrm{~mL}$ of water. After introduction of the sample solution $(1.78 \mathrm{~mL})$, the adsorbent was first washed with $1 \mathrm{~mL}$ of water/methanol (90/10, vol/vol), and the analytes were eluted with $1 \mathrm{~mL}$ of methanol. The extract was evaporated to dryness under nitrogen atmosphere at $60{ }^{\circ} \mathrm{C}$. A total of $50 \mu \mathrm{L}$ of MSTFA was added to the dried extract, which was then kept at $60^{\circ} \mathrm{C}$ for $10 \mathrm{~min}$ to derivatize the analytes. The MSTFA solution was injected to GC as such. The same sample preparation procedure was repeated to the samples with varying SARM concentrations from $10 \mathrm{pg} / \mathrm{mL}$ to $100 \mathrm{ng} / \mathrm{mL}$. In addition, six urine samples were prepared to determine recovery; three samples were spiked at the concentration level of $3 \mathrm{ng} / \mathrm{mL}$ before extraction, while the other three samples were first extracted and then spiked before the evaporation step. For the optimization of the instrumental parameters, 10 $\mu \mathrm{L}$ of stock solutions $(1 \mathrm{mg} / \mathrm{mL})$ of SARMs were evaporated to dryness, and subsequently derivatized with MSTFA similarly to the urine samples. The samples were diluted with MSTFA to obtain a working solution of $10 \mu \mathrm{g} / \mathrm{mL}$ (according to nonderivatized compounds).

\section{Fabrication of the Microchip}

The heated nebulizer microchip consisted of silicon and Pyrex glass wafers, which were bonded together by anodic bonding. The microchip featured an insertion channel for the sample capillary, an inlet for the auxiliary gas, a vaporizer channel, and an exit nozzle. The height of the vaporizer channel was $250 \mu \mathrm{m}$ and the width $800 \mu \mathrm{m}$. A detailed fabrication process of the microchip has been

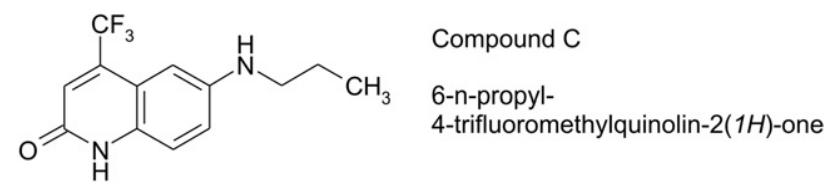


presented elsewhere [31]. A deactivated silica capillary (150 $\mu \mathrm{m}$ i.d., $220 \mu \mathrm{m}$ o.d.) for sample introduction was attached to the microchip with high temperatureresistant epoxy glue (Duralco 4703; Cotronics Corp., Brooklyn, NY, USA).

\section{Gas Chromatography and Connection to Mass Spectrometry}

An HP 5890 II gas chromatograph (Hewlett-Packard, Waldbronn, Germany) was used for chromatographic separation of the compounds. The GC was equipped with a CTC-A200S autosampler (CTC Analytics, Zwingen, Switzerland). A methyl deactivated retention gap (length $1 \mathrm{~m}$, i.d. $0.25 \mathrm{~mm}$ ) was placed before the analytical BPX5 column (length $15 \mathrm{~m}$, i.d. $0.25 \mathrm{~mm}, 5 \%$ phenyl 95\% dimethylpolysiloxane, film thickness 0.25 $\mu \mathrm{m})$ (SGE Europe Ltd., Milton Keynes, UK). Injections were done in the splitless mode, the injection volume was $1 \mu \mathrm{L}$, and the splitless time was $1 \mathrm{~min}$. The carrier gas (helium, 99.996\%; AGA, Espoo, Finland) flow was kept constant at $1.5 \mathrm{~mL} / \mathrm{min}$. The oven temperature was held at $100{ }^{\circ} \mathrm{C}$ for $1 \mathrm{~min}$, and raised to $280^{\circ} \mathrm{C}$ at $20{ }^{\circ} \mathrm{C} / \mathrm{min}$. The injector was set to $300^{\circ} \mathrm{C}$. The platinum heater on the microchip was heated using a laboratory power supply with $2.0 \mathrm{~W}$ power, corresponding to a temperature of approximately $250^{\circ} \mathrm{C}$. A heated transfer line attached the GC system to the microchip. The transfer line consisted of an original GC-MS transfer line and of an additional resistance wire heater, which were set to $300{ }^{\circ} \mathrm{C}$ and $280{ }^{\circ} \mathrm{C}$, respectively. The capillary column was drawn through the transfer line, and in the coiled resistance wire heater part a deactivated glass press-fit connector attached the GC column and the silica capillary of the microchip. The auxiliary gas line was attached to the microchip by pressing a Nanoport fluidic connector (Upchurch Scientific Inc., Oak Harbor, WA, USA) against the gas inlet with a custom-made holder. Auxiliary gas flow (nitrogen generated by Whatman 75-72 nitrogen generator; Whatman Inc., Haverhill, MA, USA) was controlled by a mass flow controller and set to $100 \mathrm{~mL} / \mathrm{min}$. In the GC- $\mu$ APCI-Orbitrap MS study, the gas chromatographic part was similar to the one described above for the triple-quadrupole MS study, except that manual injection was used instead of the autosampler. Experimental part for the GC-EI-MS study is described elsewhere [28].

\section{Mass Spectrometry}

For GC- $\mu$ APPI-MS the conventional ion source of the API3000 triple-quadrupole MS (Applied Biosystems/ MDS Technologies, Concord, Canada) was replaced by a Nanospray stand (Proxeon Biosystems A/S, Odense, Denmark) to enable the positioning of the microchip in front of the MS orifice. Ionizing photons with $10 \mathrm{eV}$ energy and a minor proportion with $10.6 \mathrm{eV}$ energy were generated by a krypton discharge UV lamp (Heraeus Noblelight, Cambridge, UK). Toluene was pumped to the auxiliary gas line with a $3 \mu \mathrm{L} / \mathrm{min}$ flow rate, mixed with the auxiliary gas flow, and vaporized to act as a dopant in photoionization. The MS/MS collision energies were optimized by running GC isothermally and injecting repeated split injections of standard solutions. Temperatures for isothermal runs were $250{ }^{\circ} \mathrm{C}, 280^{\circ} \mathrm{C}$, and $300{ }^{\circ} \mathrm{C}$ for Compounds A, B, and C, respectively. Retention times of the analytes were determined, and the MS spectra were recorded in the positive ion full scan mode, using mass range of $\mathrm{m} / \mathrm{z}$ 200-500. Finally, the SARMs were analyzed in positive ion mode using SRM with $255 \mathrm{~ms}$ cycle time. The collision energies are listed in Table 1. Three SRM ion pairs per compound were monitored for qualification, one of which was also used for quantification (Table 1). Acquisition was divided to three periods according to the retention times of the three SARMs.

Table 1. Monitored SRM ion pairs from $\mathrm{M}^{+\bullet}$ and $[\mathrm{M}+\mathrm{H}]^{+}$precursor ions of trimethylsilyl derivatized SARMs. The quantitative ion pair for $\mathrm{M}^{+}$ions is shown in bold. Collision energies, detection limits ( $\mathrm{S} / \mathrm{N} \geq 3$ ), quantitation limits $(\mathrm{S} / \mathrm{N} \geq 10)$, intra-day repeatabilities, and extraction recoveries are for $\mathrm{M}^{+} \bullet$ ions

\begin{tabular}{|c|c|c|c|c|c|c|c|}
\hline & $\begin{array}{l}\text { Three diagnostic } \\
\text { ion pairs and } \\
\text { quantitative } \\
\text { ion pair from } \\
\mathrm{M}^{+\bullet}(\mathrm{m} / \mathrm{z})\end{array}$ & $\begin{array}{l}\text { Three diagnostic } \\
\text { ion pairs from } \\
{[\mathrm{M}+\mathrm{H}]^{+}(\mathrm{m} / \mathrm{z})}\end{array}$ & $\begin{array}{l}\text { Collision } \\
\text { energy }^{a} \\
(\mathrm{eV})\end{array}$ & $\begin{array}{l}\text { Detection limit; } \\
\text { Quantitation } \\
\text { limit (ng/mL } \\
\text { in urine) }\end{array}$ & $\begin{array}{l}\text { Peak area } \\
\text { repeatability } \\
(\mathrm{RSD} \%)^{\mathrm{b}}\end{array}$ & $\begin{array}{l}\text { Retention } \\
\text { time } \\
\text { repeatability } \\
(\mathrm{RSD} \%)^{\mathrm{b}}\end{array}$ & $\begin{array}{c}\text { Recovery } \\
\text { in SPE } \\
(\%)^{c}\end{array}$ \\
\hline \multirow[t]{3}{*}{ Compound A-TMS } & $464 / 449$ & $465 / 449$ & 40 & $0.01 ; 0.03$ & 7 & 0.03 & $92 \pm 3$ \\
\hline & $464 / 395$ & $465 / 297$ & 40 & & & & \\
\hline & $464 / 297$ & $465 / 73$ & 70 & & & & \\
\hline \multirow[t]{3}{*}{ Compound B-TMS } & $356 / 341$ & $357 / 341$ & 30 & $1 ; 3$ & 5 & 0.04 & $102 \pm 6$ \\
\hline & $356 / 313$ & $357 / 311$ & 40 & & & & \\
\hline & $356 / 297$ & $357 / 297$ & 57 & & & & \\
\hline \multirow[t]{3}{*}{ Compound C-TMS } & $342 / 313$ & $343 / 327$ & 30 & $0.1 ; 0.3$ & 9 & 0.05 & $111 \pm 2$ \\
\hline & $342 / 270$ & $343 / 285$ & 55 & & & & \\
\hline & $342 / 241$ & $343 / 257$ & 55 & & & & \\
\hline
\end{tabular}

${ }^{\text {a } F o r ~} \mathrm{M}^{+\bullet}$ ions.

${ }^{\mathrm{b}}$ Averages of three concentration levels of SARMs in urine (three replicates at each level): Compound A-TMS: $0.1,3$, and $30 \mathrm{ng} / \mathrm{mL}$; Compound B-TMS: 3, 10, and $30 \mathrm{ng} / \mathrm{mL}$; Compound C-TMS: 1, 3, and $30 \mathrm{ng} / \mathrm{mL}$.

${ }^{\mathrm{c}}$ Average of three replicates. SARM concentrations: $3 \mathrm{ng} / \mathrm{mL}$ in urine. 
The demonstration of GC- $\mu$ APCI connected to a high-resolution MS was conducted by an Orbitrap MS instrument (LTQ Orbitrap; Thermo Fischer Scientific, Bremen, Germany). The microchip was placed in front of the MS orifice similar to the GC- $\mu$ APPI-MS setup described above. Corona discharge was used for ionization. The instrument was operated in positive ion full scan mode. Mass resolution value was set at 15,000, and the mass spectra were recorded with $150 \mathrm{~ms}$ cycle time using a mass range of $m / z 70-500$. The linear ion trap was operated with helium (purity grade 5.0), and nitrogen (from a nitrogen generator, CMC Instruments, Eschborn, Germany) was used in the C-trap.

\section{Results and Discussion}

\section{Chromatography}

The GC temperature program was optimized for fast and efficient separation. Full scan chromatograms and mass spectra were acquired to determine the retention times of the analytes. The analytes were completely separated from each other. Based on the MS/MS fragmentation experiments (see the Discussion section below), GC- $\mu$ APPI-MS/MS analysis was performed in SRM mode with three SRM ion pairs (Table 1). Figure 1a shows the SRM chromatograms of the analytes, obtained by summing all the SRM ion pairs. The retention times of analyte peaks were repeatable (RSDs $0.03 \%-0.05 \%$, Table 1 ), and the shapes of the peaks were narrow (peak width at half maximum typically $\sim 1.2 \mathrm{~s}$ ), which indicate the proper function of chromatography and a minimal dead volume in the microchip.

\section{Ionization and Mass Spectra}

Atmospheric pressure photoionization (APPI) and atmospheric pressure chemical ionization (APCI) are related ionization methods in respect to producing, often, the same kind of ions. Both $\mu$ APPI and $\mu$ APCI were tested as ionization devices in the present study to determine their applicability and ionization efficiency for trimethylsilylated SARMs. APPI produced both radical cations $\left(\mathrm{M}^{+\bullet}\right)$ and protonated molecules ([M + $\mathrm{H}^{+}$) whereas APCI produced only protonated molecules. The mass spectrometric responses for ionized analytes with both APPI and APCI were approximately at the same level. Fragmentation of the analytes was not observed in the MS spectra. The ratio of $\mathrm{M}^{+}$and $[\mathrm{M}+$ $\mathrm{H}]^{+}$signal intensities in APPI was $\sim 3: 2 . \mathrm{M}^{+}$ions are produced by charge exchange between the ionized dopant (toluene) and analyte molecules in APPI, whereas [M + $\mathrm{H}]^{+}$ions are produced in the proton transfer reactions between the reactant ions and the analytes in both APPI and APCI $[32,33]$.

Product ions of both $\mathrm{M}^{+}$and $[\mathrm{M}+\mathrm{H}]^{+}$precursor ions were first studied by infusion experiments with $\mu$ APPI-MS/MS. Based on these experiments, GC$\mu \mathrm{APPI}-\mathrm{MS} / \mathrm{MS}$ analysis was performed in the SRM
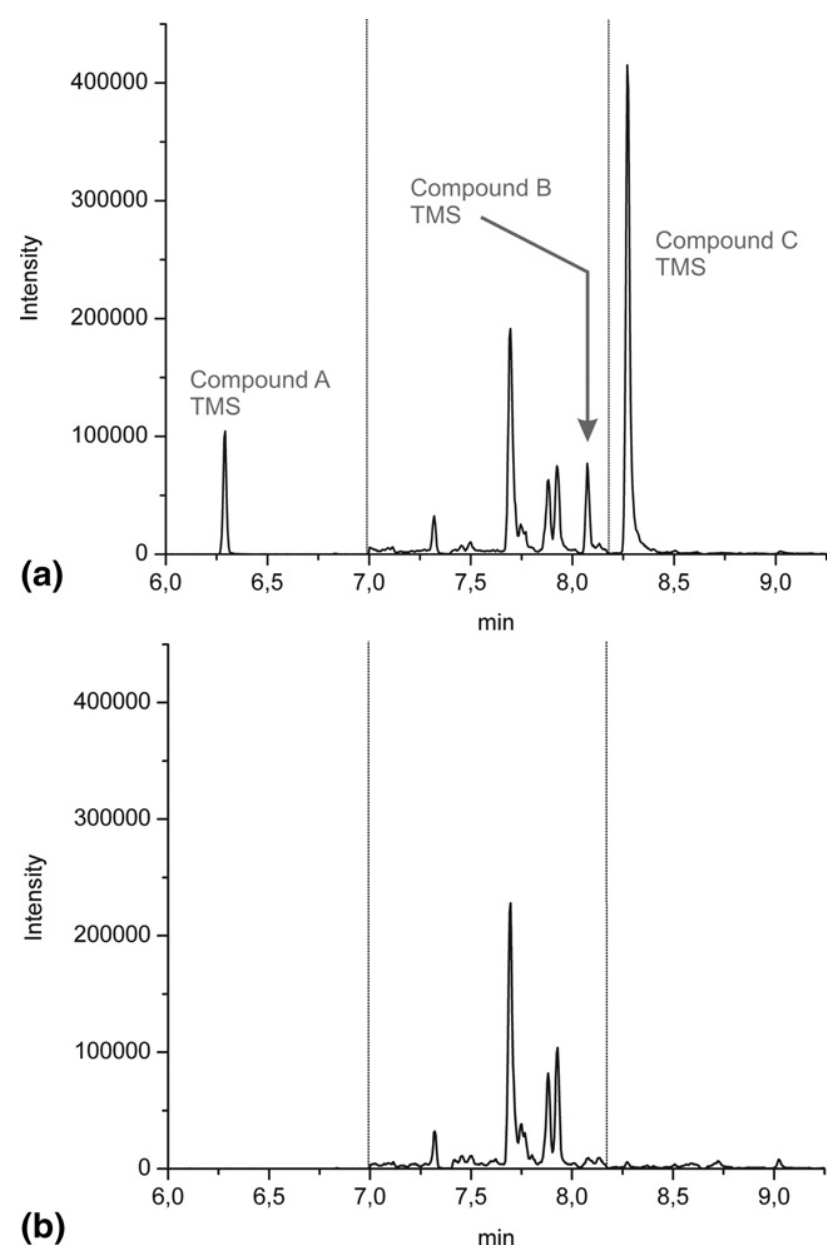

Figure 1. (a) SRM chromatograms with all SRM ion pairs from $\mathrm{M}^{+}$ions of trimethylsilylated SARMs. The analyte concentration was $10 \mathrm{ng} / \mathrm{mL}$ of nonderivatized compounds in urine. (b) SRM chromatograms of a blank urine sample.

mode using either $\mathrm{M}^{+}$or $[\mathrm{M}+\mathrm{H}]^{+}$as precursor ions (Table 1), both with three SRM ion pairs. The ion pairs from $\mathrm{M}^{+}$ions showed better signal-to-noise ratios $(\mathrm{S} / \mathrm{N})$ compared with those obtained for the ion pairs from $[\mathrm{M}+\mathrm{H}]^{+}$ions, and thus APPI was selected to be used as the ionization method, and $\mathrm{M}^{+} \cdot$ ions as the precursor ions. According to our knowledge, the APPIMS/MS spectra (Figure 2) of the studied compounds have not been published before. Figure $2 \mathrm{a}, \mathrm{b}$, and $\mathrm{c}$ show MS/MS spectra of trimethylsilyl derivatives of Compounds A, B, and C, respectively. Presented spectra are the averages of multiple MS/MS spectra obtained with different collision energies in the range 20-65 eV. From the measured product ion spectra, some peaks can be easily recognized (Figure 2). All the MS/MS spectra show TMS product ions at $m / z$ 73; peaks originating from methyl radical losses at $m / z 449$ (Figure 2a), $m / z 341$ (Figure 2b), and $m / z 327$ (Figure 2c); and molecular ion peaks at $m / z 464$ (Figure 2a), $m / z 356$ (Figure 2b), and $\mathrm{m} / \mathrm{z} 342$ (Figure 2c). Another common fragmentation route is the possible loss of $\mathrm{H}_{2} \mathrm{C}=$ $\mathrm{Si}(\mathrm{CH} 3)_{2}(72 \mathrm{u})$ from the silylated site of the analytes, forming the product ions at $m / z 392,284$, and 270 for 

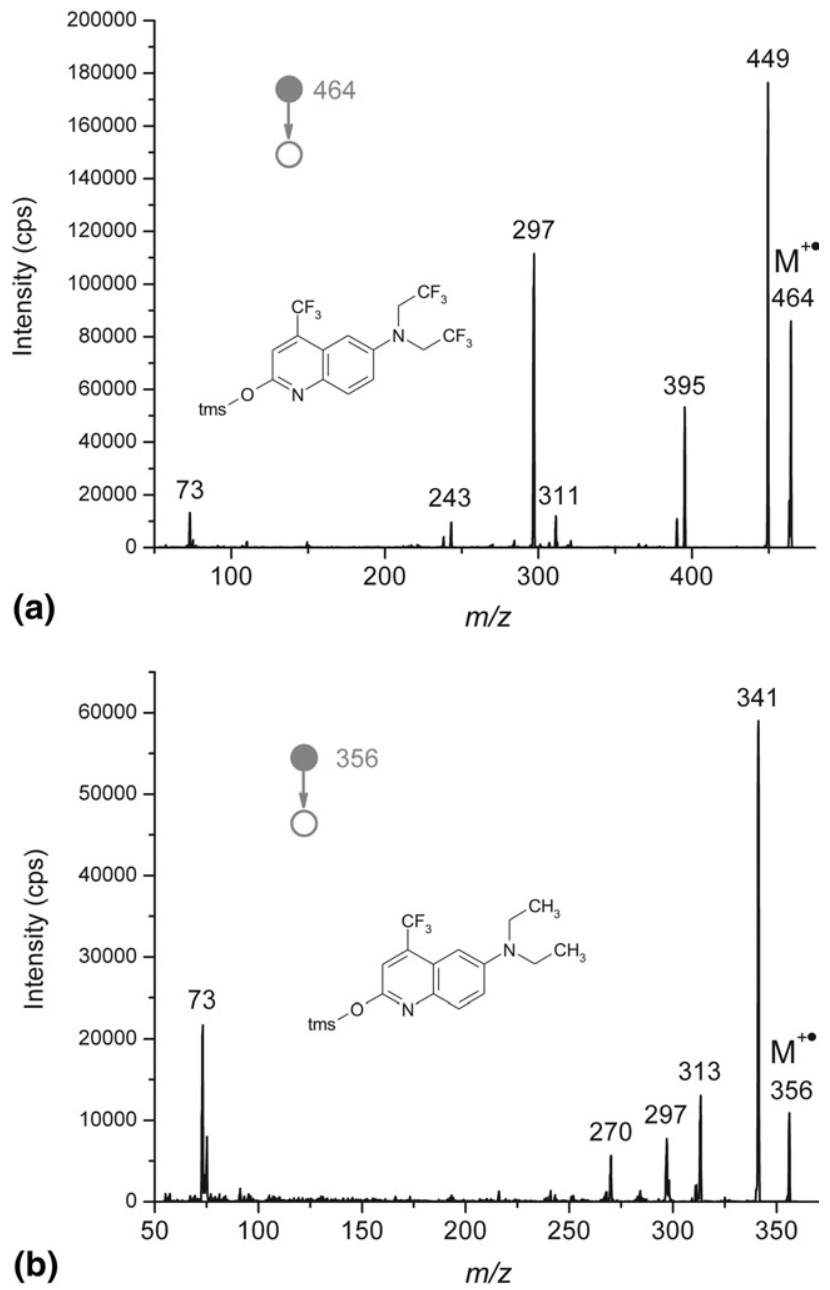

(b)

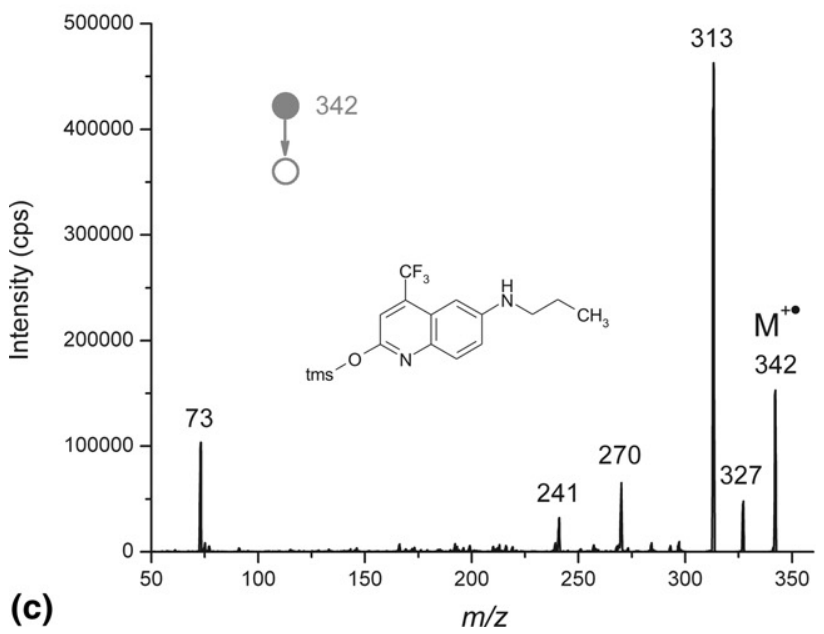

Figure 2. MS/MS spectra of the $\mathrm{M}^{+}$ions of trimethylsilylated compounds obtained from GC peaks with $\mu$ APPI. The spectra are the average spectra with different collision energies in the range 20-65 eV. (a) Compound A-TMS $\left(\mathrm{M}^{+}\right.$ion at $\left.\mathrm{m} / \mathrm{z} 464\right)$, (b) Compound B-TMS $\left(\mathrm{M}^{+} \cdot\right.$ ion at $\left.\mathrm{m} / \mathrm{z} 356\right)$, and (c) Compound C-TMS $\left(\mathrm{M}^{+} \bullet\right.$ ion at $m / z$ 342).

Compounds A, B, and C, respectively. Since APPI and electron impact ionization (EI) both produce $\mathrm{M}^{+} \bullet$ ions, similar product ions can be expected in APPI-MS/MS and EI-MS spectra, and are in fact observed. Figure 3 shows the EI-MS spectra of all the analytes. Resemblance of the mass spectra is clearly seen when comparing the APPI-MS/MS spectra in the Figure 2 to the EI-MS spectra in the Figure 3. This feature may be advantageous in analyte characterization since the APPI-MS/MS spectra of $\mathrm{M}^{+}$ions can be matched against the EI-MS spectral libraries.

\section{Analytical Performance of GC- $\mu$ APPI-MS}

The performance of the analytical method was evaluated with spiked urine samples. Trimethylsilylated compounds were detected with three diagnostic SRM ion pairs per compound. The method was observed to be selective by comparing the extracted ion chromatograms of the SRM ion pairs of a spiked urine sample and a blank urine sample (Figure 1 and Supplementary Data, which can be found in the electronic version of this article). The limits of detection (LODs) and the limits of quantitation (LOQs) were determined from single SRM ion pairs (Table 1). LODs for SARMs in urine were in the range of $0.01-1 \mathrm{ng} / \mathrm{mL}$ with $S / N \geq 3$, and LOQs in the range $0.03-3 \mathrm{ng} / \mathrm{mL}$ with $\mathrm{S} / N \geq 10$. In a previous study with LC-ESI-MS, the LODs for nonderivatized 2-quinolinone-derived SARMs in urine were reported to be in the range of $0.01-0.2 \mathrm{ng} / \mathrm{mL}$ [27], and in a study with GC-EI-MS, the LOD was $0.2 \mathrm{ng} / \mathrm{mL}$ for trimethylsilylated Compound A [28]. The World Anti-Doping Agency's minimum required performance limit for an anabolic agent is 2 or $10 \mathrm{ng} / \mathrm{mL}$ in urine, depending on the compound [34]. Our method fulfills the requirements, especially in the case of the most potent $[25,30]$ and, therefore, the most interesting Compound A, LGD-2226. There are probably two reasons for the excellent sensitivity of the method for Compound A: the compound is effectively ionized due to its high fluorine content, and there are only few background compounds originating from the urine matrix, while measuring the characteristic SRM ion pairs (Figure $1 \mathrm{~b}$ and Supplementary Data). The mass spectrometric response of the analytes was found to be linear $(R \geq 0.995$, with $1 / x$ weighting, $4-8$ concentration levels in a regression) from the LOQ concentration level up to $100 \mathrm{ng} / \mathrm{mL}$ concentration. The relative standard deviation of the peak areas in the SRM chromatograms was low (5\%-9\%) for all the compounds (Table 1 ). In addition, the extraction recovery percentages $(92 \%-111 \%)$ are acceptable and have only a little variation within three replicates $(2 \%-6 \%)$ of each compound. The method shows potential for quantitative analysis due to these characteristics. However, in doping analysis, qualitative analysis is often sufficient.

\section{Demonstration: GC- $\mu$ APCI-Orbitrap MS}

The selectivity and thus the analytical performance of the method can be further enhanced by using an MS 


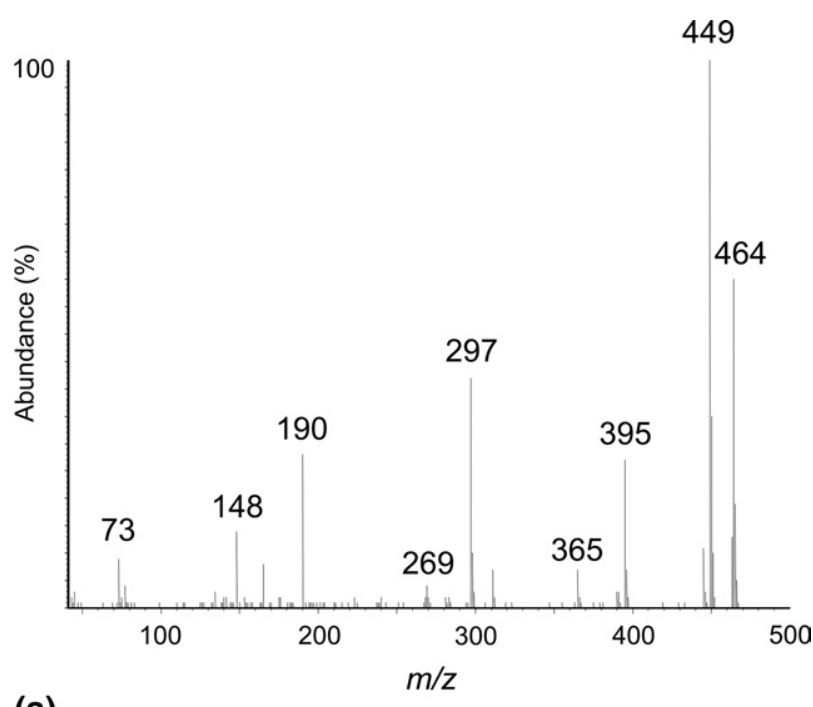

(a)

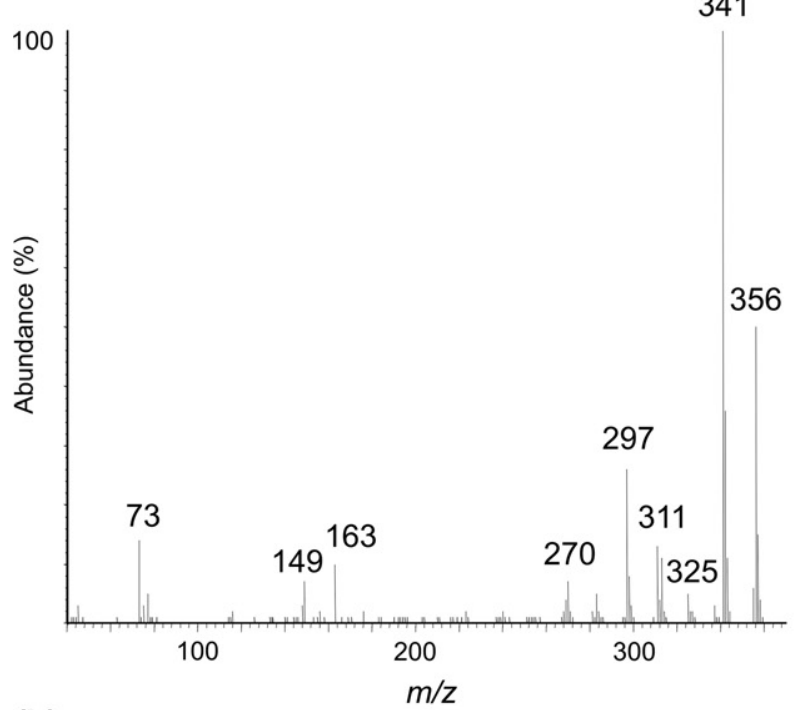

(b)

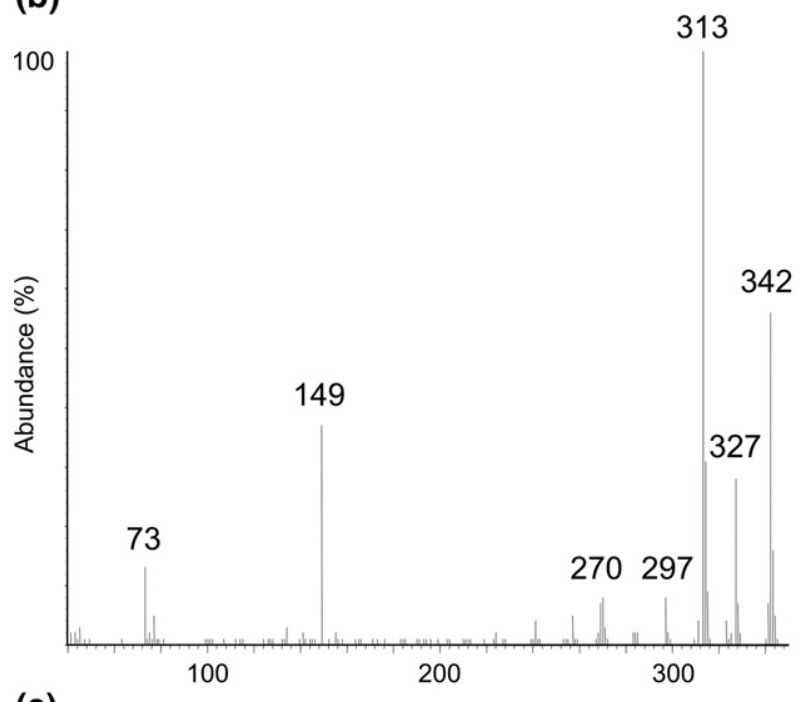

(c)

$m / z$

Figure 3. EI-MS spectra of the trimethylsilylated SARMs obtained from a GC-EI-MS run. (a) Compound A-TMS $\left(\mathrm{M}^{+} \bullet\right.$ ion at $m / z$ 464), (b) Compound B-TMS $\left(\mathrm{M}^{+\bullet}\right.$ ion at $\left.\mathrm{m} / \mathrm{z} 356\right)$, and (c) Compound C-TMS $\left(\mathrm{M}^{+} \cdot\right.$ ion at $\mathrm{m} / \mathrm{z}$ 342).

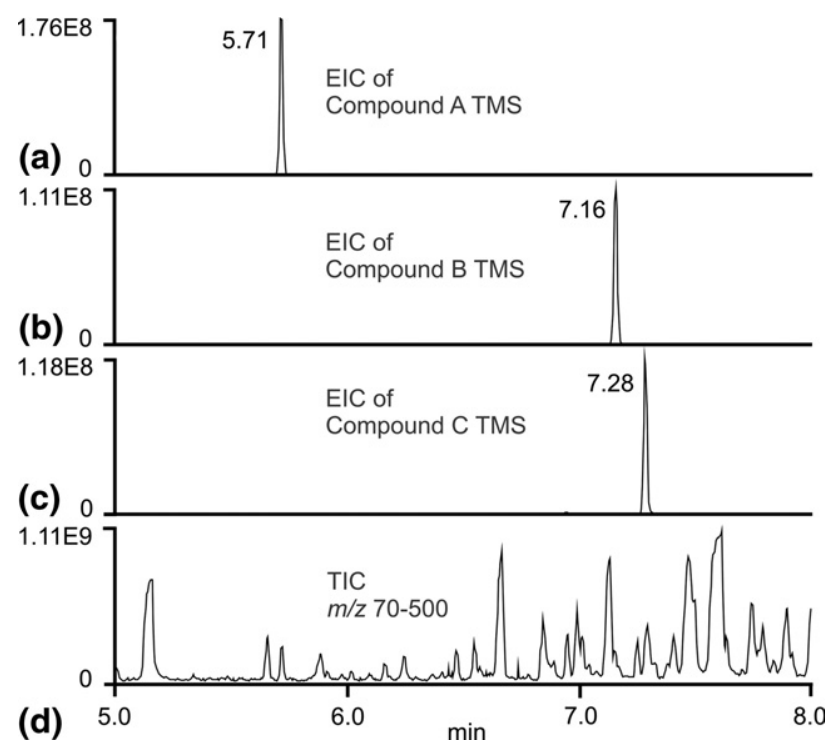

Figure 4. Extracted ion chromatograms (EIC) of the three trimethylsilylated SARMs and a total ion chromatogram (TIC) from a GC- $\mu$ APCI-Orbitrap MS run. (a) EIC at mass range $m / z$ 465.09465.12, (b) EIC at mass range $\mathrm{m} / z$ 357.15-357.18, (c) EIC at mass range $m / z$ 343.13-343.16, and (d) TIC at mass range $m / z$ 70-500. Concentration of nonderivatized analytes is $10 \mu \mathrm{g} / \mathrm{mL}$.

with a high resolving power. The combination of GC$\mu$ API with such an instrument, Orbitrap MS, was demonstrated. APCI with corona discharge was used for the ionization, and formation of $[\mathrm{M}+\mathrm{H}]^{+}$ions was clearly observed. Therefore, the analytical results obtained with this combination are not fully comparable with the results obtained with GC- $\mu$ APPI-MS using the $\mathrm{M}^{+} \cdot$ ions, but replacing the corona discharge needle with a UV lamp is possible if photoionization is favored. Extracted ion chromatograms of the $[\mathrm{M}+\mathrm{H}]^{+}$ions with a very narrow $\mathrm{m} / \mathrm{z}$ window $(0.03 \mathrm{u})$ for trimethylsilylated SARMs from a GC- $\mu$ APCI-Orbitrap MS run are presented as an example of the results (Figure 4), demonstrating the decreased background interference when accurate masses can be used for extraction of the ion chromatograms. In addition, identification of the analytes by comparing the measured accurate masses with the calculated exact masses facilitates the analysis of complex mixtures and enables a more selective and specific analysis. An excellent agreement between the measured and the calculated masses was observed (mass error $<2 \mathrm{ppm}$ ), since the measured masses of Compounds A, B, and C were $\mathrm{m} / \mathrm{z} 465.1048,357.1611$, and 343.1453, whereas the calculated masses are $\mathrm{m} / \mathrm{z}$ $465.1045,357.1610$, and 343.1453 , respectively.

\section{Conclusions}

Potential doping compounds, 2-quinolinone derived SARMs, were analyzed from urine samples. The novel analytical method, GC- $\mu$ APPI-MS, showed low limits of detection for the studied compounds, and feasibility of the heated nebulizer microchip for bioanalytical 
applications was shown. The important advantage obtained by heated nebulizer microchips is the possibility to combine efficient separation with any mass spectrometer equipped with an atmospheric pressure ionization interface. The demonstrated possibility to combine the heated nebulizer microchips with a high-resolution MS instrument empowers even more efficient GC- $\mu$ API-MS analysis. The characteristic feature of APPI, the production of radical cations, may be beneficial in analyte characterization since APPI-MS/MS spectra of radical cations can be matched against the EI-MS spectral libraries.

\section{Acknowledgments}

The authors thank the Finnish Funding Agency for Technology and Innovation (TEKES), the Graduate School of Chemical Sensors and Microanalytical Systems, and the Academy of Finland for financial support. Dr. Tiina Kauppila is acknowledged for useful comments.

\section{Appendix A Supplementary Material}

Supplementary material associated with this article may be found in the online version at doi:10.1016/ j.jasms.2009.10.019.

\section{References}

1. Erickson, D.; Li, D. Integrated Microfluidic Devices. Anal. Chim. Acta 2004, 507, 11-26.

2. Foret, F.; Kusy, P. Micro Devices in Mass Spectrometry. Eur. J. Mass Spectrom. 2007, 13, 4-44.

3. Sikanen, T.; Franssila, S.; Kauppila, T. J.; Kostiainen, R.; Kotiaho, T.; Ketola, R. A. Microchip Technology in Mass Spectrometry. Mass Spectrom. Rev. 2009, doi: 10.1002/mas. 20238, in press.

4. Wood, T. D.; Moy, M. S.; Dolan, A. R.; Bigwarfe, P. M., Jr.; White, T. P.; Smith, D. R.; Higbee, D. J. Miniaturization of Electrospray Ionization Mass Spectrometry. Appl. Spectrosc. Rev. 2003, 38, 187-244.

5. Östman, P.; Marttila, S. J.; Kotiaho, T.; Franssila, S.; Kostiainen, R. Microchip Atmospheric Pressure Chemical Ionization Source for Mass Spectrometry. Anal. Chem. 2004, 76, 6659-6664.

6. Kauppila, T. J.; Östman, P.; Marttila, S.; Ketola, R. A.; Kotiaho, T.; Franssila, S.; Kostiainen, R. Atmospheric Pressure PhotoionizationMass Spectrometry with a Microchip Heated Nebulizer. Anal. Chem. 2004, 76, 6797-6801

7. Pól, J.; Kauppila, T. J.; Haapala, M.; Saarela, V.; Franssila, S.; Ketola, R. A.; Kotiaho, T.; Kostiainen, R. Microchip Sonic Spray Ionization. Anal. Chem. 2007, 79, 3519-3523.

8. Östman, P.; Jäntti, S.; Grigoras, K.; Saarela, V.; Ketola, R. A.; Franssila, S.; Kotiaho, T.; Kostiainen, R. Capillary Liquid Chromatography-Microchip Atmospheric Pressure Chemical Ionization-Mass Spectrometry. Lab. Chip 2006, 6, 948-953.

9. Haapala, M.; Luosujärvi, L.; Saarela, V.; Kotiaho, T.; Ketola, R. A.; Franssila, S.; Kostiainen, R. Microchip for Combining Gas Chromatography or Capillary Liquid Chromatography with Atmospheric Pressure Photoionization-Mass Spectrometry. Anal. Chem. 2007, 79, 4994-4999.

10. Östman, P.; Luosujärvi, L.; Haapala, M.; Grigoras, K.; Ketola, R. A.; Kotiaho, T.; Franssila, S.; Kostiainen, R. Gas Chromatography-Microchip Atmospheric Pressure Chemical Ionization-Mass Spectrometry. Anal. Chem. 2006, 78, 3027-3031.

11. Luosujärvi, L.; Karikko, M. M.; Haapala, M.; Saarela, V.; Huhtala, S.; Franssila, S.; Kostiainen, R.; Kotiaho, T.; Kauppila, T. J. Gas Chromatography/Mass Spectrometry of Polychlorinated Biphenyls Using Atmospheric Pressure Chemical Ionization and Atmospheric Pressure Photoionization Microchips. Rapid Commun. Mass Spectrom. 2008, 22, 425431.

12. Haapala, M.; Pól, J.; Saarela, V.; Arvola, V.; Kotiaho, T.; Ketola, R. A.; Franssila, S.; Kauppila, T. J.; Kostiainen, R. Desorption Atmospheric Pressure Photoionization. Anal. Chem. 2007, 79, 7867-7872.
13. Kauppila, T. J.; Arvola, V.; Haapala, M.; Pól, J.; Aalberg, L.; Saarela, V.; Franssila, S.; Kotiaho, T.; Kostiainen, R. Direct Analysis of Illicit Drugs by Desorption Atmospheric Pressure Photoionization. Rapid Commun. Mass Spectrom. 2008, 22, 979-985.

14. Luosujärvi, L.; Laakkonen, U.-M.; Kostiainen, R.; Kotiaho, T.; Kauppila, T. J. Analysis of Street Market Confiscated Drugs by Desorption Atmospheric Pressure Photoionization and Desorption Electrospray Ionization Coupled with Mass Spectrometry. Rapid Commun. Mass Spectrom. 2009, 23, 1401-1404.

15. Cadilla, R.; Turnbull, P. Selective Androgen Receptor Modulators in Drug Discovery: Medicinal Chemistry and Therapeutic Potential. Curr. Top. Med. Chem. 2006, 6, 245-270.

16. Gao, W.; Kim, J.; Dalton, J. T. Pharmacokinetics and Pharmacodynamics of Nonsteroidal Androgen Receptor Ligands. Pharm. Res. 2006, 23, 1641-1658.

17. Buijsman, R. C.; Hermkens, P. H.; van Rijn, R. D.; Stock, H. T.; Teerhuis, N. M. Nonsteroidal Steroid Receptor Modulators. Curr. Med. Chem. 2005, 12, 1017-1075.

18. Negro-Vilar, A. Selective Androgen Receptor Modulators (SARMs): A Novel Approach to Androgen Therapy for the New Millennium. J. Clin. Endocrinol. Metab. 1999, 84, 3459-3462.

19. Gao, W.; Bohl, C. E.; Dalton, J. T. Chemistry and Structural Biology of Androgen Receptor. Chem. Rev. 2005, 105, 3352-3370.

20. Gao, W.; Dalton, J. T. Expanding the Therapeutic Use of Androgens via Selective Androgen Receptor Modulators (SARMs). Drug Discov. Today 2007, 12, 241-248.

21. Thevis, M.; Thomas, A.; Kohler, M.; Beuck, S.; Schanzer, W. Emerging Drugs: Mechanism of Action, Mass Spectrometry, and Doping Control Analysis. J. Mass Spectrom. 2009, 44, 442-460.

22. Dalton, J. T.; Mukherjee, A.; Zhu, Z.; Kirkovsky, L.; Miller, D. D. Discovery of Nonsteroidal Androgens. Biochem. Biophys. Res. Commun. 1998, 244, 1-4.

23. Yin, D.; Gao, W.; Kearbey, J. D.; Xu, H.; Chung, K.; He, Y.; Marhefka, C. A.; Veverka, K. A.; Miller, D. D.; Dalton, J. T. Pharmacodynamics of Selective Androgen Receptor Modulators. J. Pharmacol. Exp. Ther. 2003, 304, 1334-1340.

24. Edwards, J. P.; West, S. J.; Pooley, C. L.; Marschke, K. B.; Farmer, L. J.; Jones, T. K. New Nonsteroidal Androgen Receptor Modulators Based on 4-(Trifluoromethyl)-2(1H)-Pyrrolidino[3,2-g] Quinolinone. Bioorg. Med. Chem. Lett. 1998, 8, 745-750.

25. van Oeveren, A.; Motamedi, M.; Mani, N. S.; Marschke, K. B.; Lopez, F. J.; Schrader, W. T.; Negro-Vilar, A.; Zhi, L. Discovery of 6-N, $N$-Bis (2,2,2-Trifluoroethyl)Amino- 4-Trifluoromethylquinolin-2(1H)One as a Novel Selective Androgen Receptor Modulator. J. Med. Chem. 2006, 49, 6143-6146.

26. Ostrowski, J.; Kuhns, J. E.; Lupisella, J. A.; Manfredi, M. C.; Beehler, B. C.; Krystek, S. R., Jr.; Bi, Y.; Sun, C.; Seethala, R.; Golla, R.; Sleph, P. G.; Fura, A.; An, Y.; Kish, K. F.; Sack, J. S.; Mookhtiar, K. A.; Grover, G. J.; Hamann, L. G. Pharmacologic and X-Ray Structural Characterization of a Novel Selective Androgen Receptor Modulator: Potent Hyperanabolic Stimulation of Skeletal Muscle with Hypostimulation of Prostate in Rats. Endocrinology 2007, 148, 4-12.

27. Thevis, M.; Kohler, M.; Maurer, J.; Schlorer, N.; Kamber, M.; Schanzer, W. Screening for 2-Quinolinone-Derived Selective Androgen Receptor Agonists in Doping Control Analysis. Rapid Commun. Mass Spectrom. 2007, 21, 3477-3486.

28. Thevis, M.; Kohler, M.; Schlorer, N.; Fussholler, G.; Schanzer, W Screening for Two Selective Androgen Receptor Modulators Using Gas Chromatography-Mass Spectrometry in Doping Control Analysis. Eur. J. Mass Spectrom. 2008, 14, 153-161.

29. Rosen, J.; Negro-Vilar, A. Novel, Nonsteroidal, Selective Androgen Receptor Modulators (SARMs) with Anabolic Activity in Bone and Muscle and Improved Safety Profile. J. Musculoskelet. Neuronal Interact. 2002, 2, 222-224

30. van Oeveren, A.; Pio, B. A.; Tegley, C. M.; Higuchi, R. I.; Wu, M.; Jones, T. K.; Marschke, K. B.; Negro-Vilar, A.; Zhi, L. Discovery of an Androgen Receptor Modulator Pharmacophore Based on 2-Quinolinones. Bioorg. Med. Chem. Lett. 2007, 17, 1523-1526.

31. Franssila, S.; Marttila, S.; Kolari, K.; Östman, P.; Kotiaho, T.; Kostiainen R.; Lehtiniemi, R.; Fager, C.-M.; Manninen, J. A Microfabricated Nebulizer for Liquid Vaporization in Chemical Analysis. JMEMS 2006, 15, 1251-1259.

32. Kauppila, T. J.; Kuuranne, T.; Meurer, E. C.; Eberlin, M. N.; Kotiaho, T.; Kostiainen, R. Atmospheric Pressure Photoionization Mass Spectrometry. Ionization Mechanism and the Effect of Solvent on the Ionization of Naphthalenes. Anal. Chem. 2002, 74, 5470-5479.

33. Carroll, D. I.; Dzidic, I.; Stillwell, R. N.; Haegele, K. D.; Horning, E. C. Atmospheric Pressure Ionization Mass Spectrometry. Corona Discharge Ion Source in Liquid Chromatograph-Mass Spectrometer-Computer Analytical System. Anal. Chem. 1975, 47, 2369-2373.

34. World Anti-Doping Agency. Minimum Required Performance Levels for Detection of Prohibited Substances. http://www.wada-ama.org/ rtecontent/document/MINIMUM_REQUIRED_PERFORMANCE_LEVELS_ TD_v1_0_January_2009.pdf. 4.8.2009. 